\title{
THE IMPACT OF SOCIAL NETWORKING ON CUSTOMER LOYALTY IN AN EMERGING E-MARKET CONTEXT
}

\begin{abstract}
Abbiha Waqar and Nida Nabeel
Abstract. The aim of this study was to understand the impact of social networking on customer loyalty from the customers' perspective in an emerging e-market such as Pakistan, where social media penetration is still at an early stage, but is growing rapidly. The planned sample size is 100 respondents. The primary data were collected by distributing questionnaires among general public in Lahore, Pakistan from December 2016 to January 2017. The data collected were analysed using cross tabs in SPSS. The secondary data collected by analysing literature in the libraries, online journals, and published papers. Seventy four percent of the respondents agreed that website interface was of utmost importance, followed by sixty-seven percent saying that convenience of online shopping and the availability of product information are also of great importance. The findings suggest that social networking does influence the customer loyalty greatly.
\end{abstract}

Keywords: customer loyalty, e-commerce, social networking, online shopping JEL Classification: M5, M21

\section{Authors:}

\section{Abbiha Waqar}

Tokat Gaziosmanpaşa University, Gaziosmanpaşa Üniversitesi, Taşlıçiftlik Yerleşkesi, Merkez/Tokat Turkey, 60250

E-mail:abbiha.Ise@gmail.com; abbiha.waqar9320@gop.edu.tr

https://orcid.org/0000-0002-1179-3507

\section{Nida Nabeel}

Lahore School of Economics, Barki Rd, Sector P Phase 7, Lahore, Punjab 54000, Pakistan

E-mail: nida.nabeel2@gmail.com

https://orcid.org/ 0000-0002-2338-142X

Citation: Waqar, A., \& Nabeel, N. (2021). The Impact of Social Networking on Customer Loyalty in an $\begin{array}{lllll}\text { Emerging E-Market Context. Virtual } & \text { Economics. }\end{array}$ https://doi.org/10.34021/ve.2021.04.02(4) 


\section{Introduction}

Gaining and maintaining customer's loyalty have been marketers' ambition for ages (Bennett 2002). Their ultimate goal is to maintain customer relationship; as brand gains special, affirmative and prominent share of mind, they become inimitable and help in winning customer loyalty. Gaining loyalty in turn leads to sales, revenues, profitability and helps in the growth of a market share (Keller 2008; Kapfere 1997). Various means are applied by companies to uphold customer loyalty including eight Ps of marketing, brand elements, events and sponsorships, one-to-one marketing activities, internet marketing and social media marketing (Keller 2008; Kotler 2007). Customer loyalty is defined as 'an enduring desire to maintain a valued relationship' (Senders et al. 2013). Maintaining a persistent and lasting relationship with customers leads to repeat purchases, thus creating customer loyalty (Mithas et al. 2006). Wide acceptance of social media platforms and ease of sharing content among friends is another important motivation for customers to engage with brands on social media (Erdogmus \& Cicek 2012).

Using social media as a marketing tool to grab customers' attention and win their loyalty is becoming popular because social media is the most price-effectual and easy-to-use display place to communicate and share information about brands, businesses, new products and services, events and anything else (Julian, 2012).

Social media has changed and affected the consumer behaviour from end to end: from gaining information regarding the product you want to purchase to the post-purchase behaviour of gaining satisfaction or being dissatisfied. Major advantage that the social media platforms provide is connecting people with similar mindset from all over the world to each other in real time and with minimal cost, which in turn effects customer's purchase behaviour. It is due to this that social media has become a highly effective and relevant tool in most industries: that is why companies must participate and show their presence on Facebook, Twitter, Instagram and other social networking sites in order to be visible to their customers and be successful (Kaplan 2010).

\subsection{An Emerging E-Market}

Pakistan was chosen as the context of this research, as in terms of population density, it is the fourth-largest country on the Asian continent. Pakistan's growth rate of internet users is the second highest in SAARC countries. The internet users have showed double digit growth for the past five years, and now their number accounts for 16.8 percent (Ameen 2017). The active social media users' penetration rate is only 17.5 percent (Internet World Stat 2017) making it a largely untapped market to be exploited in the near future.

According to the recent study, it has been noted that Pakistan, although a late participant in the world of e-commerce, has been showing an increasing trend over the years. There is a massive rise in online shopping trends and other e-commerce businesses. Among various factors that have changed the shopping trends over time and helped in pushing e-commerce 
to the next level in Pakistan is the rate of internet penetration. Internet users, whose number was limited to approximately 30 million back in 2015, are expected to soar up to 56 million users in 2019 (Ahmad 2015).

The $3 \mathrm{G}$ and $4 \mathrm{G}$ launch back in 2014 was another major event that brought the consumers and companies much closer to each other. Many businesses were set up and had been successful due to this. Pakistan's Telecom Authority announced that after that launch the mobile subscriptions increased up to 10.3 million in 2015 (Ahmad, 2015).

The study further elaborates the next factor i.e., the increase in smart phone users, which in turn makes the online businesses much more accessible. It is due to the rise in demand of smart phones that many Chinese smart phone manufactures have set up their companies in Pakistan. With over 28 percent of the population to have access to internet by 2019 and the increase in using sites like Facebook and Twitter, the marketing strategies and companies' relationship with the customers have experienced drastic transformations, because social media has started to have a major impact on customers' opinions (Ahmad 2015). This can be exemplified by a Facebook group named "Foodies R Us", which has members all over Pakistan sharing their opinions in this group as to whether an eatery is worth trying or not. The results are made known to either, making the eatery a success or a failure.

\subsection{Problem Definition/Formulation}

Many researchers suggest that social media can help in engaging customer and building customer loyalty. To understand the depth of this relationship, different variables concerning social media with reference to customer loyalty are studied.

Most studies are localised in the countries that have high penetration rate of social media usage such as the USA, Turkey and the UK. As Pakistani social media penetration is still at an early stage of development, making it potentially an untapped market to be exploited in the near future, this research is done in order to comprehend how social media can influence customer loyalty in an emerging market.

\section{Literature Review}

Safko and Brake defined and explained social media as a "conversational media" where different people come together online in order to share their opinions, ideas and information (Safko, 2009). "Social media has altered the way people interact with each other" (Olanrewaju et al., 2020). Due to COVID-19 pandemics, social media platforms did a roaring business. Similarly, for the customers, the Web has created a superior variety of choice in terms of value, price elasticity, products and services. This is due to the fact that the internet has provided admittance of new products and companies. "The fame of the Internet and the initiation of the Web 2.0 technologies have transmuted the contents of the web from publisher-to-usercreated contents" (Ghani et al. 2019). In order to operate in highly aggressive environment, long-term relationships with customers are necessary (Bruhn et al., 2014). A study states that 
customers are more likely to recommend or purchase a company's product after they have affianced with company on social media (Jackson, 2011). The customers who are using social media came across various sources of communal information from other customers about their recommendations and experiences. If the firm is engaged in social media, it helps in creating business for customers and helps in creating enhanced value (Tajvidi \& Karami, 2021).

\subsection{Customer Loyalty}

There are two main reasons of why customer loyalty is important in modern day businesses. "Firstly, customers are a scarce resource; it is very easy to obtain a purchase from an old customer rather than from a new one. Secondly, customer loyalty has a positive effect on revenues and profitability of the company" (Castañeda, 2017). Social networking plays an important role when it comes to gaining customer loyalty, therefore this study focuses on obtaining customer loyalty through social media presence.

"Customer loyalty construct was defined as recurrent purchasing, but literature has since evolved to considering several dimensions, including behavioural, attitudinal and composite" (Närvänen et al., 2020). Literature suggests that loyalty can be categorized in two diverse ways: first is attitudinal and second is behavioural. Attitude focuses on a feeling that individual customers have in reference to the product they want to buy, service they want to avail themselves of and organization with which they want to associate; whereas the behavioural loyalty focuses on a behaviour that is repeated again and again until it becomes a habit rather than a cognitive decision (Hallowell, 1996). Customers using the same nearby store to shop even though there are other stores located nearby can be taken as an example.

\subsection{Salient Features of Social Networks}

\subsubsection{A Prerequisite for any Business Transaction}

Trust in the context of social media - "e-trust" - can largely help in building "e-loyalty". For any business transaction to take place, trust is a prerequisite. Trust along with the customer satisfaction plays an invaluable role in bringing customers back for more buys, resulting in repeat purchases and a positive impact on customer loyalty (Ribbink et al. 2004). Consumers have more trust in online information shared by the opinion leader. Consumer trust is very important in social media, as without it they are unable to purchase the product (Pop et al., 2021).

\subsubsection{Customer Satisfaction}

Customer satisfaction is a multidimensional and extensive notion. In the whole consumer life cycle, which includes brand name, after-sales service and product or service quality etc., many various variables can affect customer satisfaction and customer loyalty (Shokouhyar et al., 2020). Anderson \& Srinivasan (2003) suggest that trust and perceived value go hand in hand 
in order to accelerate the impact of customer satisfaction on customer loyalty. Customer satisfaction plays a key role in building customer loyalty. Customer satisfaction has a positive impact on customer loyalty, as there is a significant relationship. "Satisfaction is directly linked to customer experience, customers want more than just simple value"; they want businesses to give those superior services and products that are above their expectations in order to satisfy their needs and demands (Hamzah \& Shamsudin, 2020). Studies related to customer satisfaction define it as having two categories:

- transaction-specific that is the customer satisfaction comes in after a product or service has been used and customer determines whether it has been worthwhile or not, a postpurchase evaluation process (Chang \& Chen 2009); whereas

- cumulative customer satisfaction focuses on the all-inclusive experience which is based on evaluating a particular organization during a specific period of time (Chang \& Chen 2009).

\subsubsection{Readily Available Product Information}

Providing frequent and desirable information to customers on social media is inexpensive and can help companies reach out and persuade their customers to make repeat purchases (Berger 1998). Making relevant information about preferred products, status of order readily available to customers can help show the customers that companies "care" about them (Srinivasan et al. 2002). "The most noticeable form of product communication in social media is digital advertisements, but social networking sites have permitted the emergence of new layouts and elusive messages in the form of e-word of mouth (e-WOM)" (Al-Abdallah et al., 2021).

\subsubsection{The Ease of Use and Convenience}

A website interface and convenience both are interrelated; a simple and user-friendly website can minimize mistakes made by the customers and make shopping more satisfying, resulting in customer loyalty (Srinivasan et al., 2002). There has been evidence that firms which invest in enhancing their websites by hiring talented staff, using multimedia and graphics, tend to attract more customers (Chang \& Chen, 2009). Convenient social media is described as the one which reduces customers effort, has a short response time and facilitates fast transactions (Schaffer, 2000).

Many studies indicate that customers leave a website without making any purchases because they are not able to make their way through the website and, because of that, they leave the transaction incomplete. 30 percent of the customers leave a website that is not convenient (Schaffer, 2000).

Moreover, another study defines a convenient website as the one that makes it easier for the customer to finish the transactions quickly, requires very little effort by the customer and is easy to go through (Wolfinbarger \& Gilly 2003). Consumer's trust in online purchasing depends on the apparent comfort of use, website eminence, website reputation and apparent efficacy (Pop et al., 2021). 


\subsubsection{The Internet Experience}

$\mathrm{H}$. Chang and S. Chen in their study provide evidence that the internet experience can have a role to play when it comes to gaining e-loyalty (Chang \& Chen, 2009). The internet experience is referred to as customers' ability to go online and use social media to facilitate themselves. Previous research suggests that people who shop online usually tend to have had a positive experience, which makes them authoritative in comparison to inexperienced users. Ecommerce players are increasing day by day, and the customers' use of smart phones globally is increasing rapidly helping them to adopt e-commerce, which results in higher market growth (Goutam et al., 2021).

To access the World Wide Web, customers use different browsers such as Netscape, Internet Explorer and Google Chrome etc. in order to get great experience. When it comes to online shopping, it has been noted that both experienced and inexperienced users have different concerns. Thus, it has been concluded that customers who lack the internet experience are more likely not to shop online (Chang \& Chen, 2009).

\subsection{The Hypotheses}

Being in a continuous contact with customers using social media makes it easier to gain and maintain customer loyalty. Thus:

H1: Customer loyalty is positively affected by trust.

$\mathrm{H} 2$ : Customer loyalty is positively affected by customer satisfaction.

H3: Customer loyalty is positively affected by product information.

H4: Customer loyalty is positively affected by a website interface.

H5: Customer loyalty is positively affected by the perceived convenience of a website.

H6: Customer loyalty is negatively affected by the lack of the internet experience.

\section{Methods}

\subsection{Data Collection}

Data were gathered through administering a structured questionnaire. The questionnaire designed for this study were taken from the literature.

\subsection{A Sample Size}

There was drawn a sample of 100 people who were online shoppers and social media users. The sample consisted of 50 percent males and 50 percent females. The average age of the sample was 25 . About 80 percent were students (graduate and postgraduate level) and 20 percent were professionals.

\subsection{The Questionnaire Design}


The questionnaire for customer loyalty was adopted from (Chang \& Chen, 2009). The independent variables were trust, customer satisfaction, convenience, product knowledge, the internet experience and a website interface. These constructs are also used in the literature by other researchers. All items on these scales were close-ended and measured on Likert scale and multiple-choice questions.

\subsection{The Data Analysis and Interpretation}

Crosstabs and Pearson chi-square test were used to analyse data in order to test the relationship between variables and their correlation.

\subsection{Pretesting}

Pretesting was also done by gathering data from 10 respondents in order to reduce the chances of error. So, bias can minimized. After pretesting, some of the questions were eliminated and the sequences of the questions were changed. Pretesting sample was not included in the analysis and results.

\section{Results and Discussion}

The hypothesized relations among all independent variables (trust, customer satisfaction, product knowledge, convenience, the internet experience and a website interface) and dependent variable (customer loyalty) were tested using SPSS.

0.05 and greater Pearson chi-square value indicates a significant positive relationship resulting in accepting the hypotheses and vice versa. All the hypotheses of this study had a greater Pearson chi-square value than 0.05 except for one variable (lack of the internet experience) (refer to Table 1).

Table 1. Pearson Chi-square values

\begin{tabular}{cccc}
\hline Hypotheses & Relationship & Pearson Chi-square value & Results \\
\hline Trust*Customer Loyalty & Positive & 0.06 & Accept \\
\hline $\begin{array}{c}\text { Customer Satisfaction * } \\
\text { Customer Loyalty }\end{array}$ & Positive & 0.18 & Accept \\
\hline $\begin{array}{c}\text { Product Information } \\
\text { Customer Loyalty }\end{array}$ & Positive & 0.43 & Accept \\
\hline $\begin{array}{c}\text { Lack of Internet Experience } \\
* \text { Customer Loyalty }\end{array}$ & Negative & 0.03 & Reject \\
\hline $\begin{array}{c}\text { Convenience * Customer } \\
\text { Loyalty }\end{array}$ & Positive & 0.09 & Accept \\
\hline
\end{tabular}




\begin{tabular}{cccc}
\hline $\begin{array}{c}\text { Website Interface } \\
\text { Customer Loyalty }\end{array}$ & Positive & 0.13 & Accept \\
\hline
\end{tabular}

Source: Developed by the authors.

\subsection{A Trustworthy Website}

As the internet usage increases, so do frauds and fraudulent websites resulting in the lack of trust. Trustworthiness of a website is very important to customers. If a website seems authentic, it will help in taking purchase decision leading to repeat purchases and customer loyalty. Respondents support this idea, as out of 100 respondents 55 percent state that a trustworthy website is very important to them. Pearson chi-square value (0.06) also indicates a positive relationship between trust and customer loyalty.

\subsection{Customer Satisfaction}

A bad experience will result in a negative word of mouth and the lack of customer loyalty. Customer satisfaction is the one thing that guarantees repeat purchases. It plays a significant role in online shopping, and 61 percent of the customers agreed with this. Pearson chi-square value $(0.18)$ also indicates a positive relationship between customer satisfaction and customer loyalty.

\subsection{A Website Interface}

Similarly, an easy-to-use website would also result in bringing customers back. Pearson chisquare value (0.13) also indicates a positive relationship between a user-friendly website interface and customer loyalty. A website interface also plays an important role, as 74 percent of the respondents agreed with this idea.

\subsection{Product Information}

Readily available information regarding products, promotions and a company itself would make it easy for customers to know the brand. Moreover, having relevant product information readily available would mean making a quick purchase decision, and that is why readily available product information has a positive relation with customer loyalty, which it also indicated by the Pearson chi-square value (0.43). Sixty-seven percent of the customers agreed that product information helped in making an educated purchase decision.

\subsection{Convenience}

Customers who shop online are looking for convenience and a way to save time. Online shopping is convenience epitomized; and 67 percent of the respondents agree. Pearson chisquare value (0.09) also indicates a positive relationship between convenience and customer loyalty. 


\subsection{The Internet Usage and Experience}

Furthermore, 70 percent of customers use the internet twice a day and about 26 percent of the respondents said they use the internet throughout the day but frequency of internet experience does not guarantee a loyal customer base. This is also indicated by Pearson chisquare test. As the Pearson chi-square, value (0.03) also indicates a negative relationship between lack of the internet experience and customer loyalty.

\section{Conclusion and Recommendations}

The purpose of this study was to understand the "impact of social networking on customer loyalty" from customer's standpoint. It has been hoped that the outcome of this study contributes to practice and literature, since social media marketing has been defined as a fastgrowing platform for building long lasting relationships with customers and portraying a positive image of the brands in customer's mind. Social networking is eagerly explored by many companies all over the world in the countries that have the higher internet usage rate but not in emerging markets. Therefore, research was needed to insure some tenor in this quest.

\subsection{Limitations and Future Research}

Time constraint was the major limitation to this study, because of which large sample size could not be analysed. The other limitation was geographical boundaries, due to which only specific areas of Lahore were targeted. Moreover, validation by any quantitative statistical analysis in order to test relationship between dependent and independent variables was not done.

Due to the fact, that this research was based on convenient sampling and the number of respondents was limited as well, care should be taken to generalize the results as those true for any and all research. As the data was collected mostly from students who did not lack internet experience, the future research could be generalized, if survey filled by diverse group of people. Future research could also focus on the specific features of a website and how is can influence a customer to return for more.

\subsection{Managerial Implications}

It was interesting to see the managerial implications of this study by analysing the relationship that exist among some important variables (trust, customer satisfaction, product information, a website interface and convenience) with the customer loyalty.

The results of the study show that website interface plays a vital role in building customer loyalty leading to the conclusion that any and all marketers who are willing to take advantage of this upcoming trend in Pakistan need to invest in improving their website interface by investing time, money and human resources. 
Other factors are also important in order to build customer loyalty and they have a positive relationship with customer loyalty except for one variable i.e., a lack of the internet experience. The lack of the Internet experience has a negative relationship with customer loyalty because the greater internet experience does not affect customer loyalty. The people who use the internet daily might not visit the social websites frequently.

\section{References}

Ahmad, J. (2015). The Encouraging Future of E-Commerce in Pakistan. Karachi, Pakistan: The Express Tribune.

Al-Abdallah, G., Khaira, N., \& Elmarakby, R. (2021). The Impact of Social Networking Sites on Luxury Vehicles Purchase Decision Process in Gulf Cooperation Council Countries. Journal of International Consumer Marketing. http://doi.org/10.1080/08961530.2020.1867023

Ameen, Y. (2017). Aboard the Democracy Train. Retrieved from http://www.aboardthedemocracytrain.com/pakistan-has-highest-growth-rate-of-internet-usersin-region

Anderson, R. E., \& Srinivasan, S. S. (2003). E-Satisfaction and E-Loyalty: A Contingency Framework. Psychology \& Marketing, 20(2), 123-138. https://doi.org/10.1002/mar.10063

Bennett, R. S.-T. (2002). A Comparison of Attitudinal Loyalty Measurement Approaches. Brande Management, 9, 193-209. https://doi.org/10.1057/palgrave.bm.2540069

Berger, M. (1998). It's Your Move: Internet and Databases. Sales and Marketing Management, 150, 4449.

Bruhn, M., Schnebelen, S., \& Schäfer, D. (2014). Antecedents and Consequences of the Quality of ECustomer-to-Customer Interactions in B2B Brand Communities. Industrial Marketing Management, 43(1), 164-176. https://doi.org/10.1016/j.indmarman.2013.08.008

Castañeda, J. A. (2017). Relationship between Customer Satisfaction and Loyalty. Journal of Business and Psychology, 26(3), 371-383.

Chang, H., \& Chen, S. (2009). The Impact of Customer Interface Quality, Satisfaction and Switching Costs on E-Loyalty Internet Experience as a Moderator. Computers in Human Behavior, 24(6), 2927-2944. https://doi.org/10.1016/j.chb.2008.04.014

Ghani, N. A., Hamid, S., Hashem, I. A., \& Ahmed, E. (2019). Social media big data analytics: A survey. Computers in Human Behavior, 417-428.

Goutam, D. G. B., \& Ganguli, S. (2021). Determinants of Customer Loyalty Dimensions: E-Commerce Context in Emerging Economy Perspective. Journal of Electronic Commerce in Organizations, 1-23.

Hallowell, R. (1996). The Relationships of Customer, Satisfaction, Customer Loyalty, and Profitability: An Empirical Study. International Journal of Service Industry Management, 7, 27-42. https://doi.org/10.1108/09564239610129931

Hamzah, A. A., \& Shamsudin, M. F. (2020). Why Customer Satisfaction is Important to Business? Journal of Undergraduate Social Science and Technology, 1(1), 1-14. Retrieved from http://abrn.asia/ojs/index.php/JUSST/article/view/58

Internet World Stat. (2017, July 10). Retrieved from http://www.internetworldstats.com/asia.htm 
Erdogmus, I.E., \& Cicek, M. (2012). The Impact of Social Media Marketing on Brand Loyalty. Procedia Social and Behavioral Sciences, 58, 1353-1360.

Jackson, N. (2011, May). Info Graphic: Using social Media to Build Brand Loyalty. Retrieved from http://www.thealantic.com/technology/archive/2011/07/infographic-using-social-media-tobuild-brand-loyalty/241701/

Julian, L. (2012). Using Social Media to Increase Consumer Loyalty to a Brand. San Luis Obispo: California Polytechnic State University.

Kapfere, J. (1997). Stategic Brand Managemnt: Creating and Sustaining Brand Equity Lomg Term. UK: Kogan Page.

Kaplan, A. M. (2010). Users of the World, Unite! The Challenges and Opportunities of Social Media. Business Horizons, 53, 59-68.

Keller, K. (2008). Startegic Brand Management: Building, Measuring and Managing Brand Equity. New Jersey: Pearson Prentice Hall.

Kotler, P. K. (2007). A Framework for Marketing Management. Third Edition. New Jersey: Pearson Prentice Hall.

Mahmood, A., \& Ahmad, W. (2017). Export Performance of Pakistan: Role of Structural Factors. Pakistan: State Bank of Pakistan.

Manfred Bruhn, S. S. (2014). Antecedents and consequences of the quality of e-customer-to-customer interactions in B2B brand communities. Industrial Marketing Management, 43(1), 164-176.

Närvänen, E., Kuusela, H., Paavola, H., \& Sirola, N. (2020). A meaning-based framework for customer loyalty. International Journal of Retail \& Distribution Management, 48(8), 825-843. https://doi.org/10.1108/IJRDM-05-2019-0153

Nyambane, E. N. (2013). Determinents of Mackahoo's Country Manufacturing Sector Competititveness and Applicability of Porter's Diamond Model. Nairobi: School of Business, University of Nairobi.

Olanrewaju, A.-S. T., Hossain, M. A., Whiteside, N., \& Mercieca, P. (2020). Social media and entrepreneurship research: A literature review. International Journal of Information Management, 50, 90-110. https://doi.org/10.1016/j.ijinfomgt.2019.05.011

Pop, R.-A., Săplăcana, Z., Dabija, D.-C., \& Alta, M.-A. (2021). The impact of social media influencers on travel decisions: the role of trust in consumer decision journey. Current Issues in Tourism, 1-17. https://doi.org/10.1080/13683500.2021.1895729

Mithas, S., Ramasubbu, N., Krishnan, M.S., \& Fornell, C. (2006). Designing Web Sites for Customer Loyalty across Business Domains: A Multilevel Analysis. Journal of Management Information Systems, 23(3), 97-127. https://doi.org/10.2753/MIS0742-1222230305

Ribbink, D., van Riel, A.C.R., Liljander, V., \& Streukens, S. (2004). Comfort your online customer: quality, trust and loyalty on the internet. Managing Service Quality: An International Journal, 14(6), 446456. https://doi.org/10.1108/09604520410569784

Safko, L. (2009). The Social Media Bible. New Jersey: John Wiley \& Sons, Inc.

Shokouhyar, S., Shokoohyar, S., \& Safari, S. (2020). Research on the influence of after-sales service quality factors on customer satisfaction. Journal of Retailing and Consumer Services, 56, 102139. https://doi.org/10.1016/j.jretconser.2020.102139

Schaffer, E. (2000). Better way for Web Design. Information Week, 784, 194.

Senders, A. Govers, R., \& Neuts, B. (2013). Social Media Affecting Tour Operators' Customer Loyalty. Journal of Travel \& Tourism Marketing, 30(1-2), 41-57. https://doi.org/10.1080/10548408.2013.750993 
Srinivasan, S.S., Anderson, R., \& Ponnavolu, K. (2002). Customer Loyalty in E-commerce: an Exploration of its antecendents and cosequences. Journal of Retailing, 78(1), 41-50. https://doi.org/10.1016/S0022-4359(01)00065-3

Tajvidi, R., \& Karami, A. (2021). The effect of social media on firm performance. Computers in Human Behavior, 115, 105174. https://doi.org/10.1016/j.chb.2017.09.026

WITS. (2018). Economy of Pakistan. Washington D.C, United States of America: World Bank.

Wolfinbarger, M. \& Gilly, M.C. (2003). eTailQ: dimensionalizing, measuring and predicting etail quality. Journal of Retailing, 79(3), 183-198. https://doi.org/10.1016/S0022-4359(03)00034-4 